\title{
International Space Station Nickel-Hydrogen Battery On-Orbit Performance
}

Penni Dalton

Glenn Research Center, Cleveland, Ohio

Fred Cohen

The Boeing Company, Canoga Park, California 
The NASA STI Program Office ... in Profile

Since its founding, NASA has been dedicated to the advancement of aeronautics and space science. The NASA Scientific and Technical Information (STI) Program Office plays a key part in helping NASA maintain this important role.

The NASA STI Program Office is operated by Langley Research Center, the Lead Center for NASA's scientific and technical information. The NASA STI Program Office provides access to the NASA STI Database, the largest collection of aeronautical and space science STI in the world. The Program Office is also NASA's institutional mechanism for disseminating the results of its research and development activities. These results are published by NASA in the NASA STI Report Series, which includes the following report types:

- TECHNICAL PUBLICATION. Reports of completed research or a major significant phase of research that present the results of NASA programs and include extensive data or theoretical analysis. Includes compilations of significant scientific and technical data and information deemed to be of continuing reference value. NASA's counterpart of peerreviewed formal professional papers but has less stringent limitations on manuscript length and extent of graphic presentations.

- TECHNICAL MEMORANDUM. Scientific and technical findings that are preliminary or of specialized interest, e.g., quick release reports, working papers, and bibliographies that contain minimal annotation. Does not contain extensive analysis.

- CONTRACTOR REPORT. Scientific and technical findings by NASA-sponsored contractors and grantees.
- CONFERENCE PUBLICATION. Collected papers from scientific and technical conferences, symposia, seminars, or other meetings sponsored or cosponsored by NASA.

- SPECIAL PUBLICATION. Scientific, technical, or historical information from NASA programs, projects, and missions, often concerned with subjects having substantial public interest.

- TECHNICAL TRANSLATION. Englishlanguage translations of foreign scientific and technical material pertinent to NASA's mission.

Specialized services that complement the STI Program Office's diverse offerings include creating custom thesauri, building customized data bases, organizing and publishing research results... even providing videos.

For more information about the NASA STI Program Office, see the following:

- Access the NASA STI Program Home Page at http://wwo.sti.nasa.gov

- E-mail your question via the Internet to help@stinasa.gov

- Fax your question to the NASA Access Help Desk at 301-621-0134

- Telephone the NASA Access Help Desk at 301-621-0390

- Write to: NASA Access Help Desk NASA Center for AeroSpace Information 7121 Standard Drive Hanover, MD 21076 


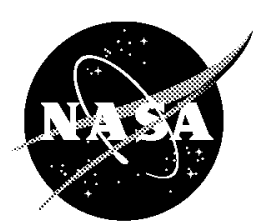

\section{International Space Station Nickel-Hydrogen Battery On-Orbit Performance}

Penni Dalton

Glenn Research Center, Cleveland, Ohio

Fred Cohen

The Boeing Company, Canoga Park, California

Prepared for the

37 th Intersociety Energy Conversion Engineering Conference sponsored by the Institute of Electrical and Electronics Engineers, Electron Devices Society

Washington, DC, July 28-August 2, 2002

National Aeronautics and Space Administration

Glenn Research Center 
Available from

NASA Center for Aerospace Information 7121 Standard Drive

Hanover, MD 21076
National Technical Information Service 5285 Port Royal Road Springfield, VA 22100

Available electronically at hite//gltrs.grcnasagov/CLTRS 
IECEC2002-20091

\title{
INTERNATIONAL SPACE STATION NICKEL-HYDROGEN BATTERY ON-ORBIT PERFORMANCE
}

\author{
Penni Dalton \\ National Aeronautics and Space Administration \\ Glenn Research Center \\ Cleveland, Ohio 44135 \\ 216-433-5223 \\ penni.j.dalton@grc.nasa.gov \\ Fred Cohen \\ The Boeing Company \\ Rocketdyne Propulsion and Power \\ Canoga Park, California 91309 \\ 818-586-3206 \\ fred.cohen@west.boeing.com
}

\begin{abstract}
International Space Station (ISS) Electric Power System (EPS) utilizes Nickel-Hydrogen $\left(\mathrm{Ni}_{2} \mathrm{H}_{2}\right)$ batteries as part of its power system to store electrical energy. The batteries are charged during insolation and discharged during eclipse. The batteries are designed to operate at a $35 \%$ depth of discharge (DOD) maximum during normal operation.

Thirty-eight individual pressure vessel (IPV) Ni$\mathrm{H}_{2}$ battery cells are series-connected and packaged in an Orbital Replacement Unit (ORU). Two ORUs are series-connected utilizing a total of 76 cells, to form one battery. The ISS is the first application for low earth orbit (LEO) cycling of this quantity of seriesconnected cells.

The P6 (Port) Integrated Equipment Assembly (IEA) containing the initial ISS high-power components was successfully launched on November 30,2000 . The IEA contains 12 Battery Subassembly ORUs (6 batteries) that provide station power during eclipse periods. This paper will discuss the battery performance data after eighteen months of cycling.
\end{abstract}

\section{INTRODUCTION}

At Assembly Complete (AC), the ISS Electric Power System (EPS) will be powered by 24 batteries during eclipse and extended operation periods. The batteries are evenly divided between four Integrated Equipment Assemblies (IEA), as part of the four photovoltaic modules (PVM). The fourth and final PVM will complete the EPS and is currently scheduled for launch in January, 2004. The battery
ORU (see Fig. 1) is designed to operate for 6.5 years, with a mean-time-between-failure (MTBF) of 5 years, when run in the reference design 35\% Depth of Discharge (DOD) low earth orbit (LEO) regime. Typical expected discharge currents can range from $<25$ Amps in a low-demand orbit to as high as $~ 75$ Amps to meet short peaking load requirements at a battery operating voltage range of 76 to $123 \mathrm{Vdc}$. The ORUs are individually fused to protect the ISS EPS from fault propagation that could result from a cell-to-EPS ground event. Primary charge control is accomplished by a pressure temperature algorithm, which incorporates acceptance test data in order to initialize basic reference parameters.

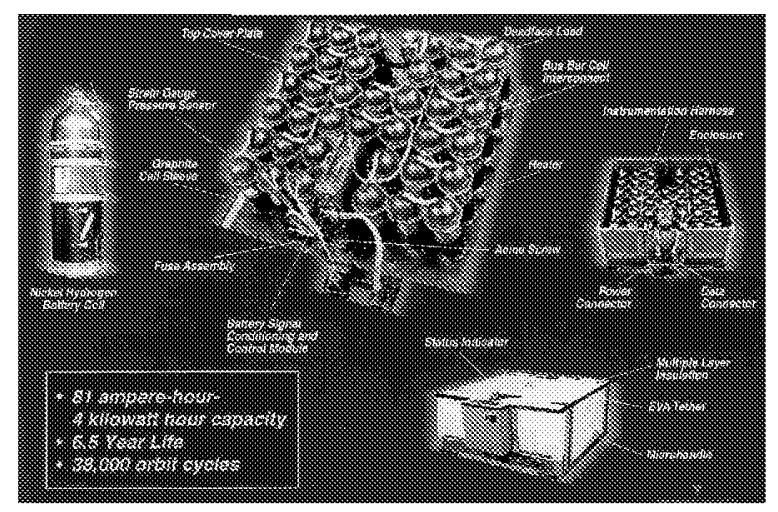

FIGURE 1. ISS BATTERY SUBASSEMBLY ORU 
The ISS power system is the first on-orbit use of such a large quantity of series-connected individual pressure vessel (IPV) $\mathrm{Ni}-\mathrm{H}_{2}$ battery cells, in an ORU/Battery (38/76 cells) configuration. Previous ground testing had been performed on 22 IPV NiH cells in series (Lowery, et al., 1990). Therefore, during the ISS program development stage, it was important to demonstrate that the "as-designed" battery could be successfully run. This was accomplished at the Power Systems Facility (PSF) Laboratory at NASA Glenn (then NASA Lewis) Research Center in Cleveland, Ohio in 1992. Two Engineering Model ORUs in series were subjected to 3,000 LEO peaking cycles at $35 \%$ DOD. The test demonstrated that the ORUs exceeded the ISS design requirements for electrical performance, heat generation, thermal uniformity, and charge management (Cohen and Dalton, 1994).

\section{ORU DESIGN CONSIDERATIONS}

Remembering that the original ISS battery design effort began in 1988, a long-life, high-performance battery was needed. Therefore, state-of-the-art $\mathrm{Ni}-\mathrm{H}_{2}$ IPV chemistry was chosen at that time, and designed to meet the following ORU requirements:

- 6.5-year design life

- 81-Amp-hr nameplate capacity to limit the maximum reference DOD to less than $35 \%$

- Contingency orbit capability consisting of one additional orbit at reduced power after a $35 \%$ DOD without recharge

- 5-year MTBF

- Easy on-orbit replacement utilizing the robotic arm.

The cells selected for use in the Battery ORUs are manufactured by Eagle Picher Industries. The cells are RNH-81-5 EPI IPV NiH to-back plate configuration. They are activated with $31 \%$ potassium hydroxide $(\mathrm{KOH})$ electrolyte. The ORUs are assembled and acceptance tested by Space Systems/Loral.

\section{ISS BATTERY CONFIGURATION}

The Battery Subassembly ORU, as designed and built, is pictured below in Figs. 2 and 3 .

$\mathrm{NiH}_{2}$ cells for the current 12 ISS Battery ORUs were manufactured and activated 3.6 to 4.4 years prior the November 30, 2000 launch date. The flight ORUs were used for IEA systems ground testing and final checkout, but were stored open-circuit, discharged, and at $-10^{\circ} \mathrm{C}$ when they were not in use.

Twelve Battery ORUs were integrated onto the P6 IEA in July 2000 at the Kennedy Space Center (KSC). These 12 ORUs comprise six separate batteries, with three batteries on each of two power channels. For the P6 IEA, these power channels are designated as $2 \mathrm{~B}$ and $4 \mathrm{~B}$. During insolation, power is supplied to the source bus by solar arrays that meet the demands of user loads as well as battery recharging. The batteries interface through a Battery Charge/Discharge Unit (BCDU) and provide the power to the source bus for the ISS during eclipse periods.

Each ORU is individually fused for fault propagation protection of the EPS in the event of a cell short. The 120-amp fuse block consists of two parallel fuse strings, one 60 ampere string on each power cable. The fuses are constructed using high voltage, high reliability space rated components. Each battery ORU also contains a letdown resistor that connects across the power terminals and provides the capability to individually discharge the hardware at the ORU level.

The battery ORU contains a Battery Signal Conditioning and Control Module (BSCCM). The BSCCM provides conditioned battery monitoring signals from the ORU to the Local Data Interface (LDI) located within the BCDU. Available data includes 38 cell voltages, four pressure (strain gauge) readings, six cell and three baseplate temperatures. This data is provided as an analog multiplexed voltage. A separate signal provides ORU total voltage output. The BSCCM also accepts and executes commands from the BCDU/LDI to control $\mathrm{ORU}$ cell heater and resistor letdown functions.

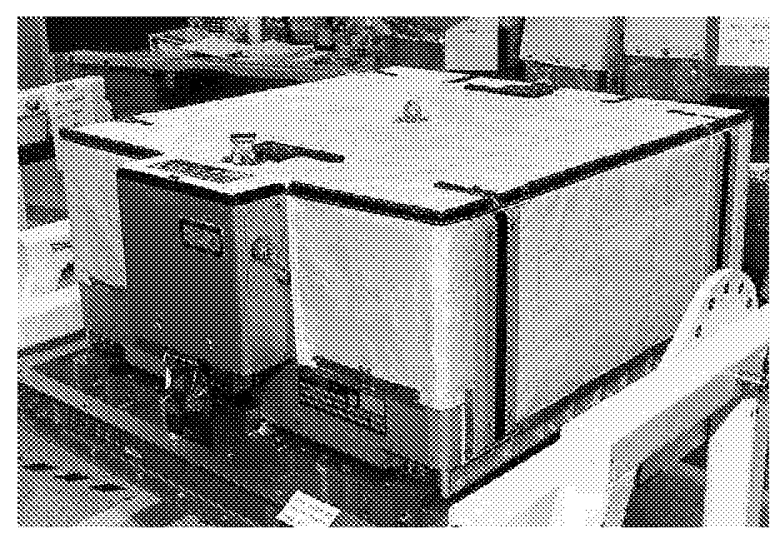

\section{FIGURE 2. ISS BATTERY SUBASSEMBLY ORU WITH MLI BLANKET}

For battery charging, the BCDU conditions power from the $160 \mathrm{~V}$ source bus and charges the battery at pre-determined currents that are calculated based on State of Charge (SOC). The charging algorithm, based on a temperature and pressure SOC calculation, was described in a previous paper (Cohen and Dalton, 2001). During periods of eclipse, the BCDU extracts power from the battery, conditions this power, and supplies power to the source bus. 


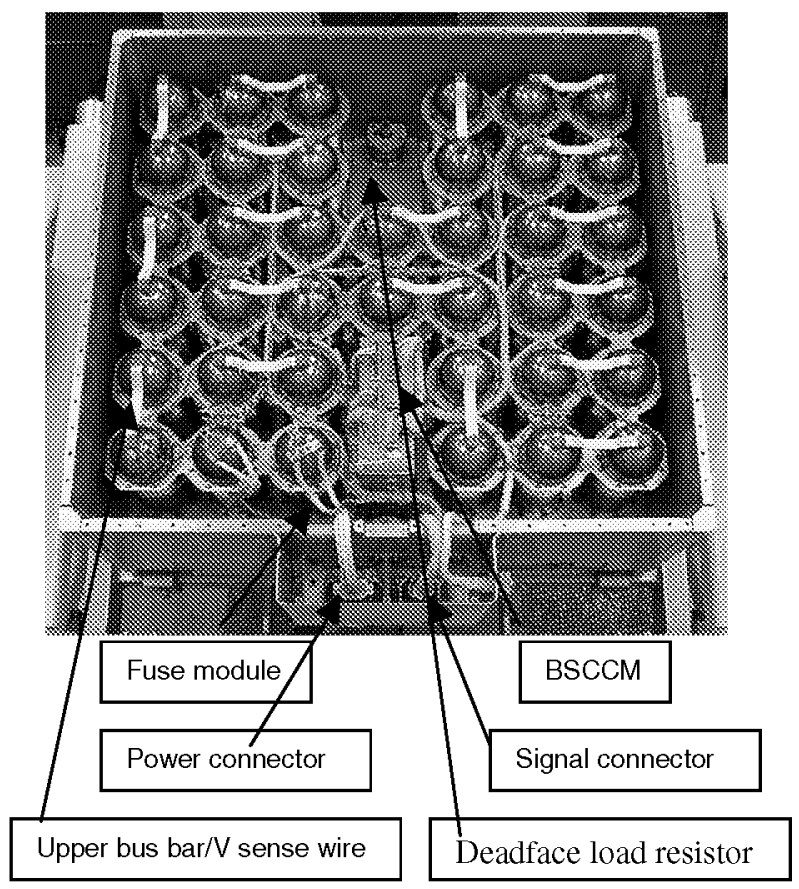

FIGURE 3. ISS FLIGHT MODEL BATTERY SUBASSEMBLY ORU WITH COVER REMOVED

The batteries are actively cooled using the ISS Thermal Control System (TCS). The battery cells are assembled in an ORU box, using a unique finned radiant heat exchanger baseplate. The ORU is then mounted on the IEA using ACME screws and mated to the TCS. The TCS was designed to maintain the Battery ORUs at a nominal operating temperature range of $5 \pm 5^{\circ} \mathrm{C}\left(41 \pm 9^{\circ} \mathrm{F}\right)$ with minimum heater operation when run at a $35 \%$ DOD LEO regime.

\section{ISS ON-ORBIT OPERATION}

The ISS main power system charge algorithm has pre-set parameters. Maximum charge rate is determined and set based on the on-orbit operation need. Currently, a 50-Amp maximum charge rate setpoint is employed due to operating scenarios that feather arrays to save fuel and/or reduce the possibility of charge build-up on the ISS structure during EVA activity. As such, it is necessary to replenish the battery energy used during eclipse as quickly as possible when it is available from the solar arrays. The taper charge profile is pre-programmed in a look-up table with the following parameters:

\begin{tabular}{|l|l|l|l|l|l|l|l|l|l|}
\hline SOC $\%$ & 20 & 85 & 90 & 94 & 96 & 98 & 1.00 & 1.01 & $>1.05$ \\
\hline $\begin{array}{c}\text { Chg Rate } \\
\text { (Amps) }\end{array}$ & 50 & 50 & 50 & 50 & 40 & 27 & 10 & 5 & 1 \\
\hline
\end{tabular}

The above table is on-orbit programmable and can be revised to allow optimal charge rates for changing operational scenarios, as well as for compensation of changing battery performance characteristics caused by aging.

\section{ISS ON-ORBIT DATA}

The ISS on-orbit data is telemetered to the ground, and is available real time through data screens on consoles located in the Engineering Support Rooms (ESRs) and the Mission Engineering Room (MER). Stored, long-term data can be accessed from the Orbiter Data Reduction Complex (ODRC) through the consoles. The on-orbit start-up procedures and the battery initial performance were reported by Cohen and Dalton, 2001.

Representative, current on-orbit data is shown following the text in Figs. 6 through 15. This data is for flight days 117 (April 27, 2002) for channel 2B and 124 (May 4, 2002) for channel 4B. As of these dates, the batteries had completed approximately 8,200 and 8,300 LEO cycles respectively. The data depicts one battery for each channel. Spaces in the data are caused by data drop-out and are not intentional omissions. The data clearly shows that the batteries are performing within their design specifications over the operational range.

For the referenced data:

- Battery voltage (76 cells) 95 to $117 \mathrm{Vdc}$ (Figures 6 and 7 )

- Maximum charge rate 50 Amps (note that due to ISS EPS conventions, charging current is shown as negative)

- Cell voltages $\sim 1.25$ to $\sim 1.55 \mathrm{Vdc}$ (Figures 8 and 9)

- Average ORU temperature range $\sim 0.0$ to $4.4^{\circ} \mathrm{C}$ (Note heater cycling due to ISS operation at less than ORU power design loads) (Figures 10 and 11)

- Average battery pressure $\sim 563$ to $\sim 720 \mathrm{psi}$ (note: 4B2 delta pressures between ORUs) (Figures 12 and 13)

- Average SOC $\sim 80 \%$ to $\sim 104 \%$ (Note: Batteries on both channels are operating well below DOD design point, with 4B running at lighter load than 2B) (Figures 14 and 15)

The cycling regime has been fairly benign over the last 18 months, averaging closer to $20 \%$ DOD than the designed-for DOD of $35 \%$. Figure 4 is a plot of actual and predicted DODs based on projected power levels. As shown in the plot, actual DODs to date have ranged from a low of $10 \%$ to a high of $35 \%$. Power level projections (Gonzalez, 2001) have been used to predict the DOD during the remainder of the P6 batteries on-orbit operation. These predictions range from $16 \%$ to $38 \%$ DOD, with an average of 
about $26 \%$ DOD. Using the Space Systems Loral performance-based battery design life model, figure 5 , and these predicted DODs, the P6 battery life is expected to exceed the 6.5 year life requirement.

ISS On Orbit, Battery DOD for P6 IEA
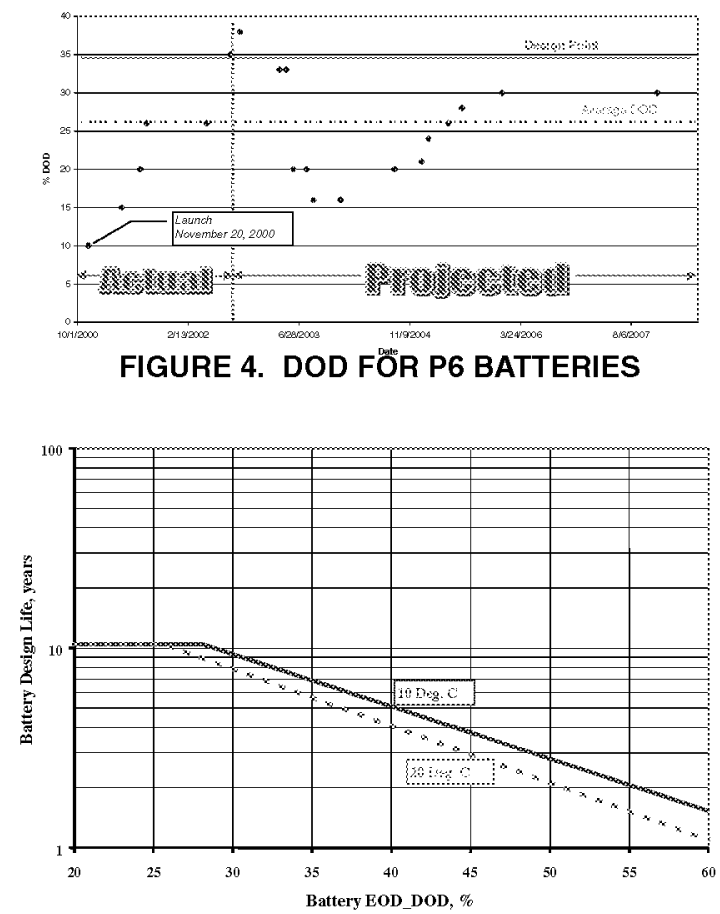

FIGURE 5. BATTERY DESIGN LIFE MODEL

Note in Figure 13 that battery 4B2 has exhibited a pressure divergence between the two ORUs. The divergence has grown with cycling. Battery 4B2 contains a mismatched set of ORUs. In the Battery $4 \mathrm{~B} 2$, ORU 4B2A has had more ground testing than ORU 4B2B. The ORUs are charged as a pair, but the SOC, and thus the charge rates, are based on the average of the SOC for the two ORUs. This led to an undercharge of $4 \mathrm{~B} 2 \mathrm{~B}$, and a slight overcharge of 4B2A.

A reinitialization procedure for the battery was performed in February, 2002. The battery was discharged during eclipse, with no charge during insolation periods, until the first cell reached $0.7 \mathrm{~V}$. The individual ORU drain resistors were then engaged. Each ORU was discharged through the resistor until the first cell reached $0.1 \mathrm{~V}$. At the completion of this procedure, the pressure difference had dropped from a high of about 160 psi to 42 psi.
The capacity of $4 \mathrm{~B} 2 \mathrm{~B}$ was estimated to be $56 \mathrm{Ah}$ and the capacity of $4 \mathrm{~B} 2 \mathrm{~A}$ was around $76 \mathrm{Ah}$. The total useable battery capacity will be limited by the 4B2B capacity of $56 \mathrm{Ah}$, however, at this time it is sufficient to meet ISS requirements.

Additional attempts to equalize the pressures and capacities of these two ORUs will be performed later this year. We have proposed increasing the operating temperature by $2^{\circ} \mathrm{C}$ and engaging the drain resistor on $4 \mathrm{~B} 2 \mathrm{~A}$, as well as raising the taper charge current on both ORUs. A more detailed description of the reinitialization will be reported in a second paper (Hajela and Cohen, 2002).

\section{CONCLUSIONS}

The ISS EPS is successfully maintaining power for all on-board loads. This power is currently supplied by six $\mathrm{NiH}_{2}$ batteries (three per channel) during eclipse periods. The batteries are designed for a LEO 35\% DOD cycle, however, due to the low power demands at this point in the ISS assembly phase, they have been operating between 10 and $35 \%$ DOD. The batteries are operating nominally and have exceeded all ISS requirements. The power system will be complete following the scheduled launch of the second, third, and fourth PVMs in April and August of 2002 and January of 2004.

\section{REFERENCES}

Cohen, F., and Dalton, P.J., "Space Station Nickel-Hydrogen Battery Orbital Replacement Unit Test," Proceedings of the $29^{\text {th }}$ Intersociety Energy Conversion Engineering Conference, Monterey, CA., August 1994.

Cohen, F., and Dalton, P.J., "International Space Station Nickel-Hydrogen Battery Start-up and Initial Performance," Proceedings of the $36^{\text {th }}$ Intersociety Energy Conversion Engineering Conference, Savanah, GA., August 2001.

Gonzalez, F., "ISS Integrated Energy Balance Analysis - Preliminary DAC9, Revision F," Houston, TX, January 2001.

Hajela, G, and Cohen, F, "Battery ReInitialization on the Photovoltaic Module of the International Space Station," Proceedings of the $36^{\text {th }}$ Intersociety Energy Conversion Engineering Conference, Savanah, GA., August 2001.

Lowery, J.E., Lanier, J.R., Hall, C.I., and Whitt, T.H., "Ongoing Nickel-Hydrogen Energy Storage Device Testing at George C. Marshall Space Flight Center," Proceedings of the $25^{\text {th }}$ Intersociety Energy Conversion Engineering Conference, Reno, NV, August 1990. 


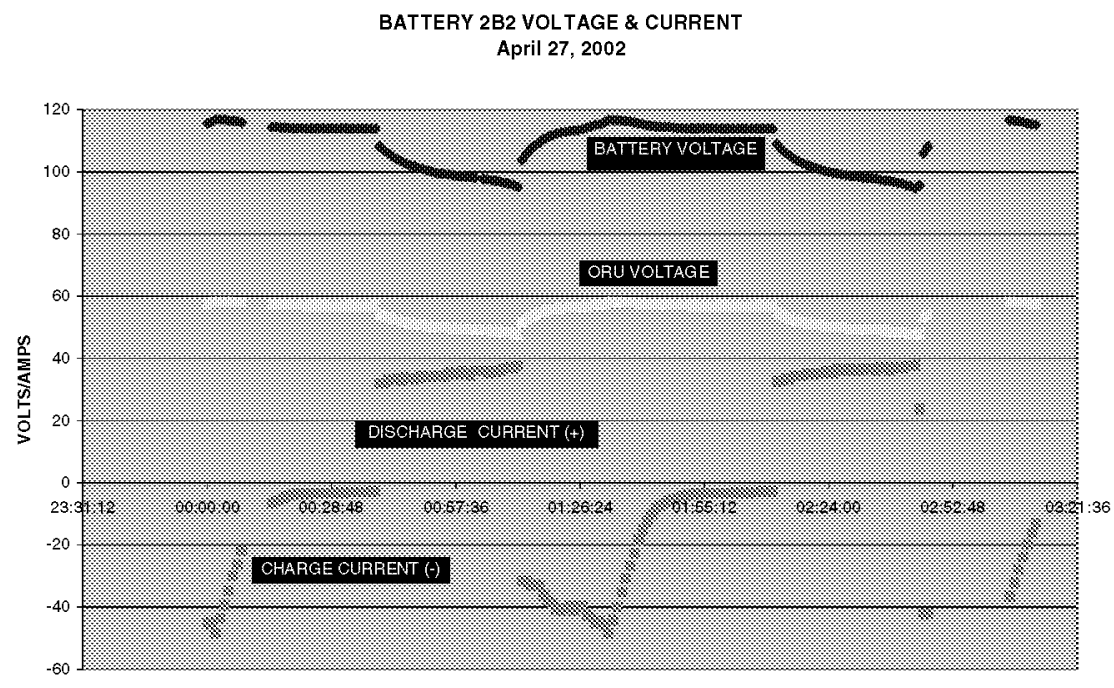

GMT TIME

Batt Volt * Batt Curr * BattA Volt $\%$ BattB Volt

FIGURE 6. BATTERY 2B2 VOLTAGE AND CURRENT

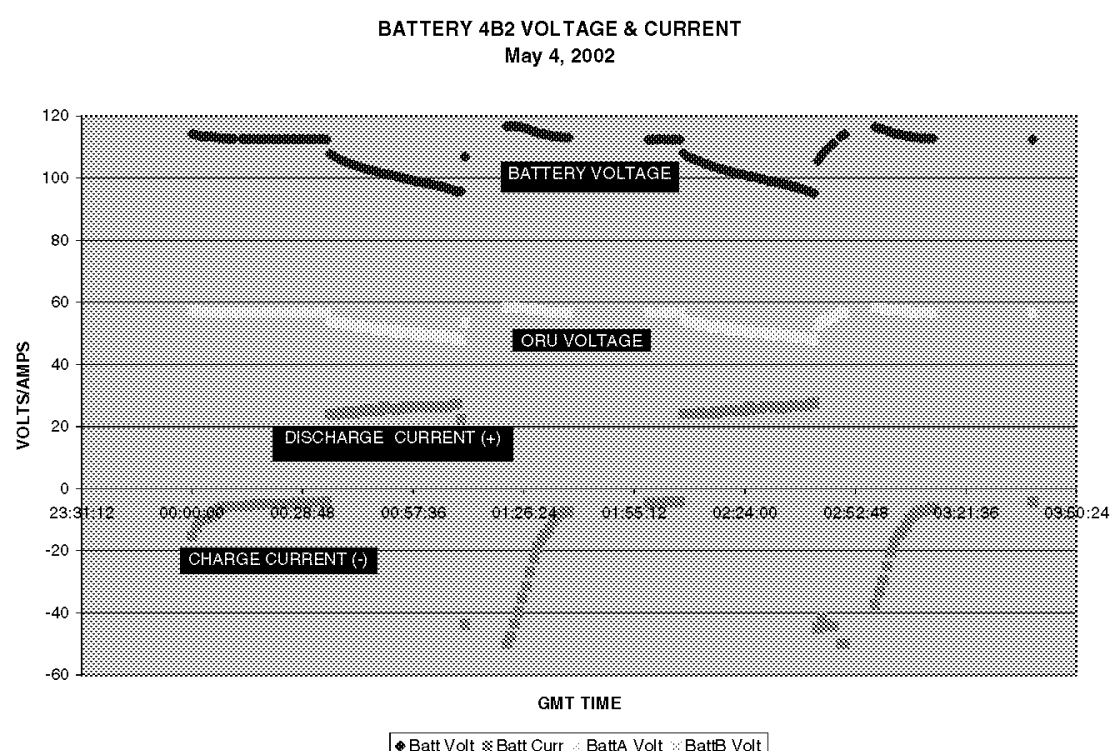

FIGURE 7. BATTERY 4B2 VOLTAGE AND CURRENT

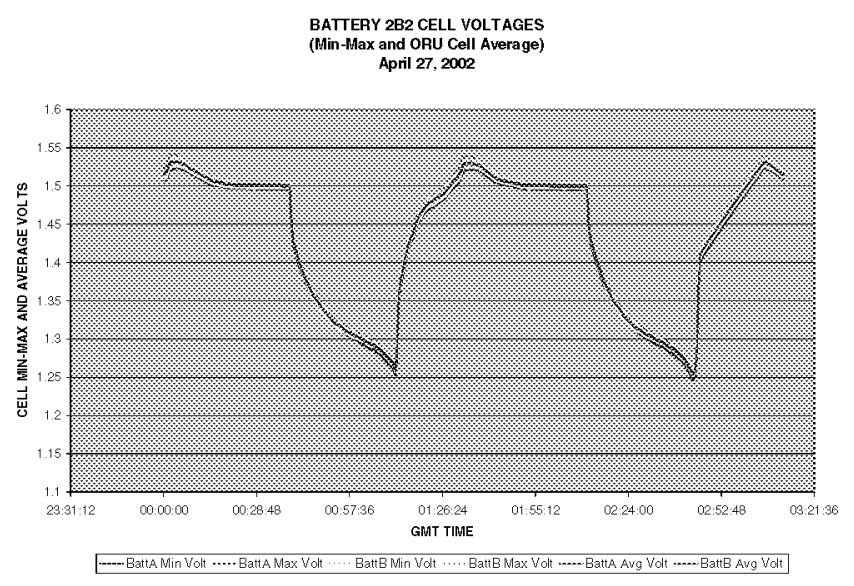

FIGURE 8. BATTERY 2B2 CELL VOLTAGES

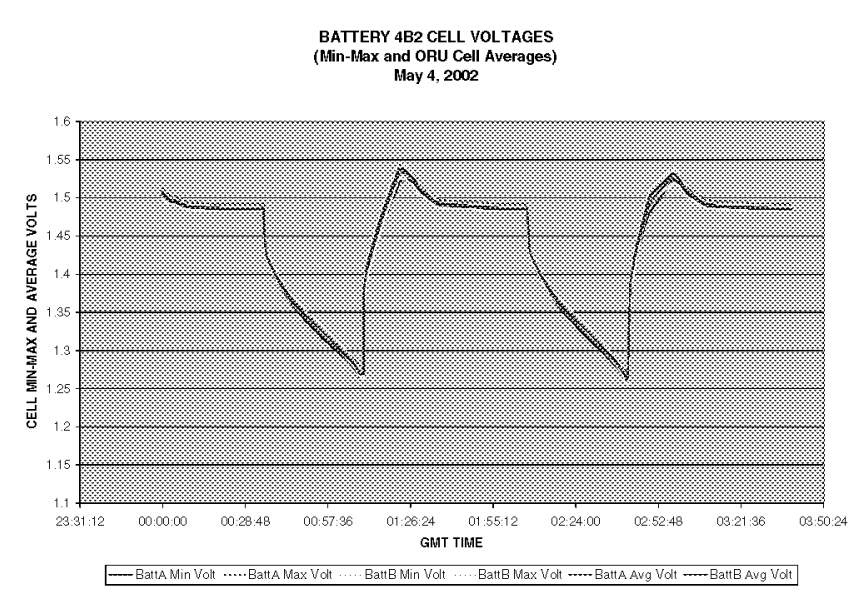

FIGURE 9. BATTERY 4B2 CELL VOLTAGES

NASA/TM-2002-211721 
BATTERY 2B2 TEMPERATURES

April 27, 2002

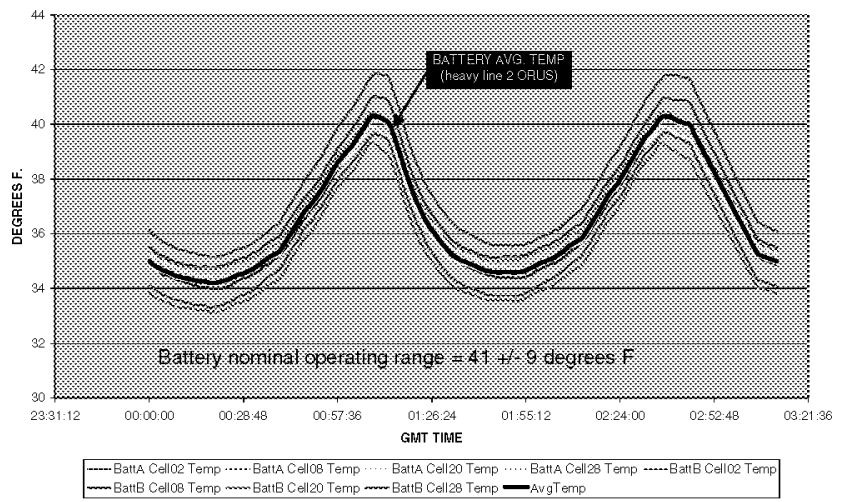

FIGURE 10. BATTERY 2B2 TEMPERATURES

BATTERY 2B2 PRESSURES April 27,2002

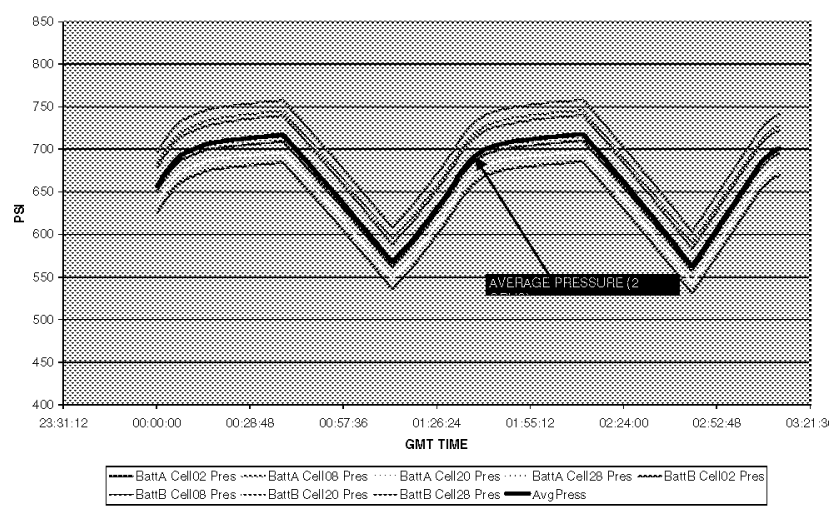

FIGURE 12. BATTERY 2B2 PRESSURES

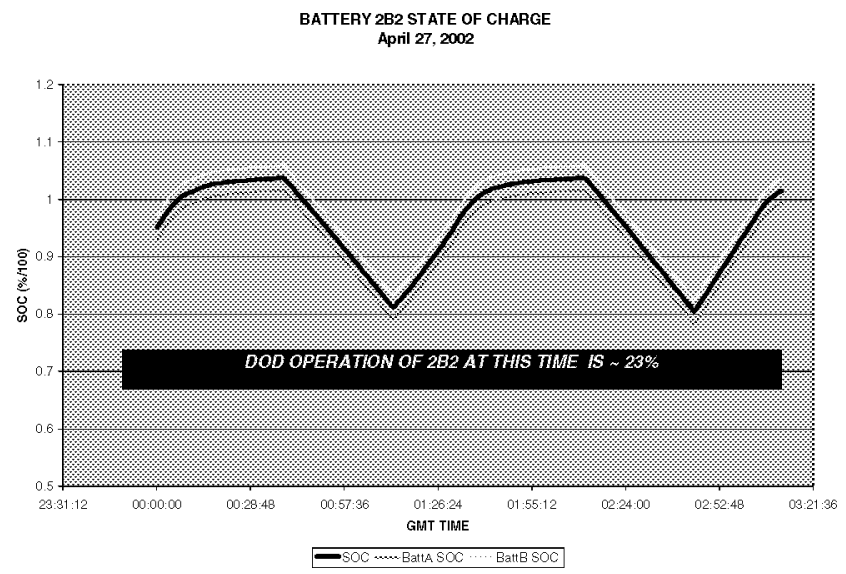

FIGURE 14. BATTERY 2B2 SOC
BATTERY 4B2 TEMPERATURES

May 4,2002

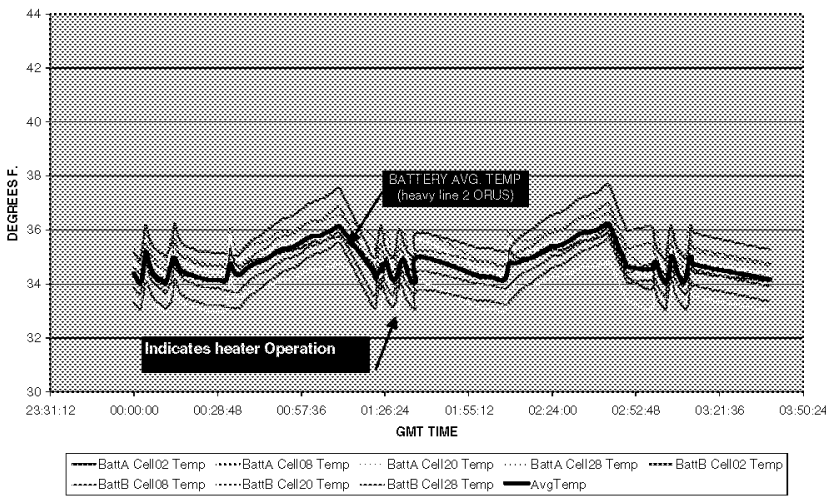

FIGURE 11. BATTERY 2B2 TEMPERATURES

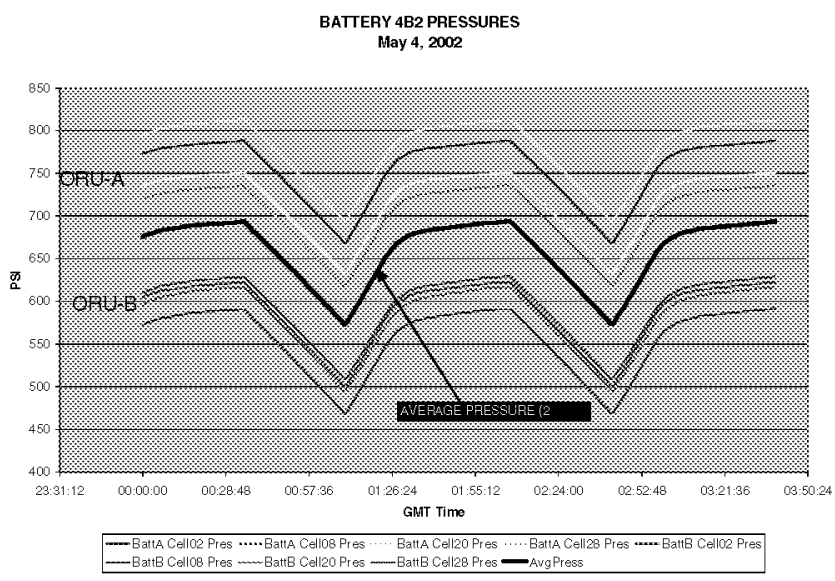

FIGURE 13. BATTERY 2B2 PRESSURES

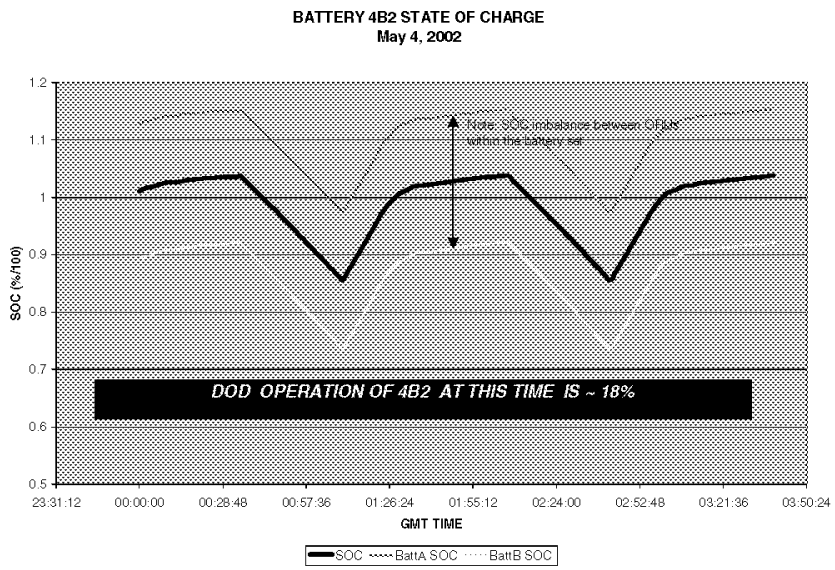

FIGURE 15. BATTERY 2B2 SOC 


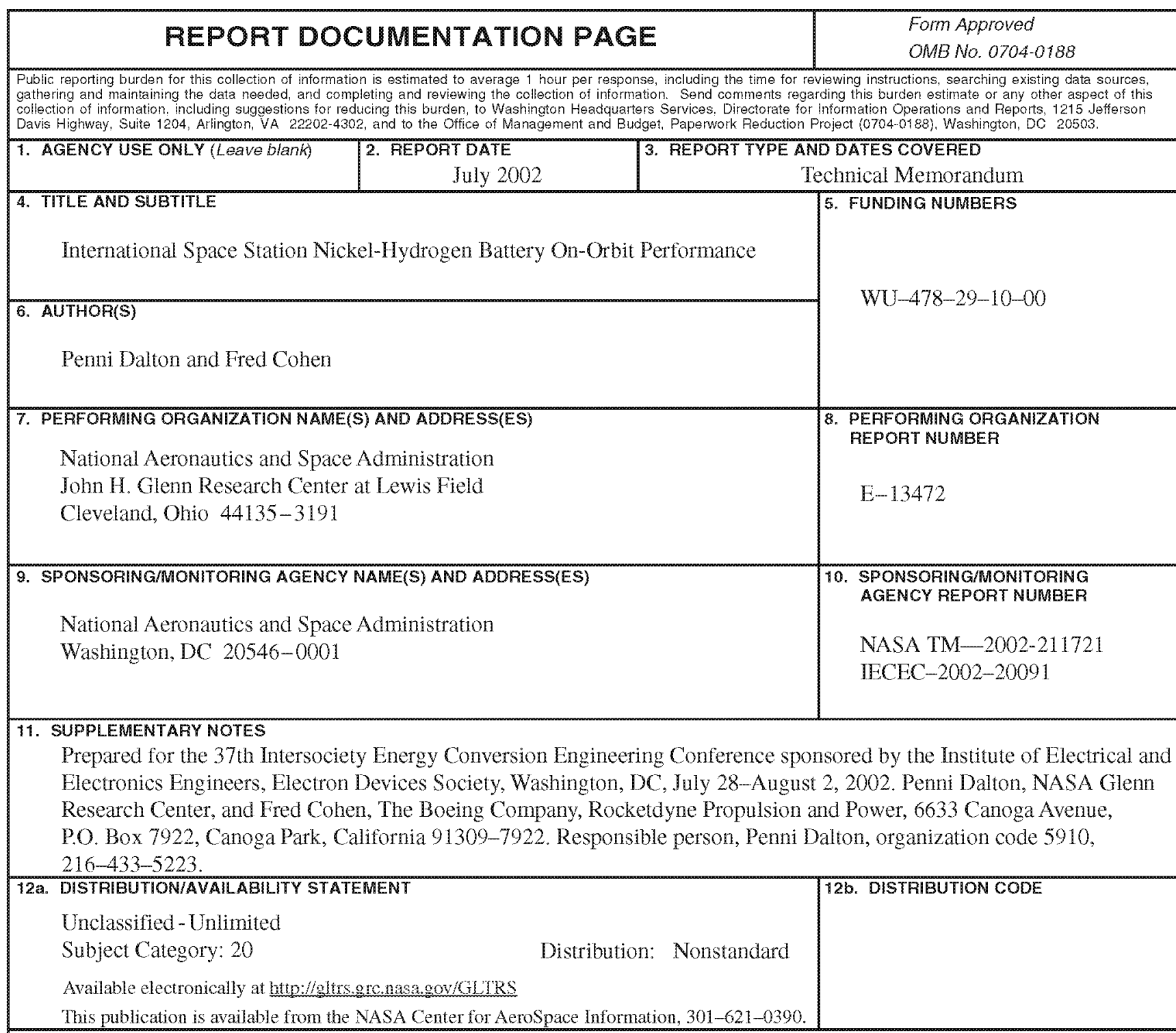

13. ABSTRACT (Maximum 200 words)

International Space Station (ISS) Electric Power System (EPS) utilizes Nickel-Hydrogen (Ni-H, batteries as part of its power system to store electrical energy. The batteries are charged during insolation and discharged during eclipse. The batteries are designed to operate at a 35 percent depth of discharge (DOD) maximum during normal operation. Thirtyeight individual pressure vessel (IPV) $\mathrm{Ni}-\mathrm{H}_{2}$ battery cells are series-connected and packaged in an Orbital Replacement Unit (ORU). Two ORUs are series-connected utilizing a total of 76 cells to form one battery. The ISS is the first application for low earth orbit (LEO) cycling of this quantity of series-connected cells. The P6 (Port) Integrated Equipment Assembly (IEA) containing the initial ISS high-power components was successfully launched on November $30,2000$. The IEA contains 12 Battery Subassembly ORUs ( 6 batteries) that provide station power during eclipse periods. This paper will discuss the battery performance data after eighteen months of cycling.

\begin{tabular}{|c|c|c|c|}
\hline \multirow{2}{*}{\multicolumn{3}{|c|}{ Battery; Nickel-hydrogen; ISS power }} & $\begin{array}{l}\text { 15. NUMBER OF PAGES } \\
12\end{array}$ \\
\hline & & & 16. PRICE CODE \\
\hline $\begin{array}{l}\text { 17. SECURITY CLASSIFICATION } \\
\text { OF REPORT } \\
\text { Unclassified }\end{array}$ & $\begin{array}{l}\text { 18. SECURITY CLASSIFICATION } \\
\text { OF THIS PAGE } \\
\text { Unclassified }\end{array}$ & $\begin{array}{l}\text { 19. SECURITY CLASSIFICATION } \\
\text { OF ABSTRACT } \\
\text { Unclassified }\end{array}$ & 20. LIMITATION OF ABSTRACT \\
\hline NSN 7540-01-280-5500 & & & $\begin{array}{l}\text { indard Form } 298 \text { (Rev. 2-89) } \\
\text { Scribed by ANSI Std. Z39-18 } \\
-102\end{array}$ \\
\hline
\end{tabular}

